\title{
Gustav Adolf Beckmann, Die Karlamagnús-Saga I und ihre altfranzösische Vorlage
}

\section{G. Matteo Roccati}

\section{(2) OpenEdition}

1 Journals

\section{Édition électronique}

URL : https://journals.openedition.org/studifrancesi/4563

DOI : 10.4000/studifrancesi.4563

ISSN : 2427-5856

Éditeur

Rosenberg \& Sellier

\section{Édition imprimée}

Date de publication : 1 avril 2012

Pagination : 115

ISSN : 0039-2944

\section{Référence électronique}

G. Matteo Roccati, « Gustav Adolf Beckmann, Die Karlamagnús-Saga I und ihre altfranzösische Vorlage », Studi Francesi [En ligne], 166 (I | LVI) | 2012, mis en ligne le 30 novembre 2015, consulté le 19 novembre 2021. URL : http://journals.openedition.org/studifrancesi/4563 ; DOI : https://doi.org/ 10.4000/studifrancesi.4563

Ce document a été généré automatiquement le 19 novembre 2021.

\section{(c) $(1) \ominus$}

Studi Francesi è distribuita con Licenza Creative Commons Attribuzione - Non commerciale - Non opere derivate 4.0 Internazionale. 


\title{
Gustav Adolf Beckmann, Die Karlamagnús-Saga I und ihre altfranzösische Vorlage
}

\author{
G. Matteo Roccati
}

\section{RÉFÉRENCE}

GUSTAV ADOLF BECKMANN, Die Karlamagnús-Saga I und ihre altfranzösische Vorlage, Tübingen, Max Niemeyer Verlag, 2008 («Beihefte zur Zeitschrift für romanische Philologie», 344), pp. viii-260.

$1 \quad$ L'essentiel de l'ouvrage (pp. 68-194) est constitué d'un commentaire des noms propres (personnages, lieux, événements) de la première branche de la Karlamagnus-Saga. Cette étude fouillée et documentée apporte-dans quelques chapitres de synthèse-des précisions sur la localisation des faits (Pierrepont, dans la région de Liège, en est le point focal, au centre du triangle Bitburg - Tongres - Aix-la-Chapelle) dans l'histoire de Basin, récit dont la source française est inconnue. A partir de cette localisation l'A. propose un scénario sur le contexte de production du texte (le même que celui des versions néerlandaises du XIII ${ }^{\mathrm{e}} \mathrm{s}$. de Floovant et Renaut de Montauban). La bibliographie (pp. 225-244) et les index (noms propres, personnages réels et littéraires, textes littéraires et historiques; pp. 249-260) complètent le volume. 